\title{
The Role of Religious Values in the Management of National Economy: A Paradigm for Economic Reform Policy in Contemporary Nigeria
}

\author{
Ushe Mike Ushe, Ph.D \\ Christian Theology Unit School of Arts and Social Sciences National Open University of Nigeria
}

\begin{abstract}
Since the early 1980s, the Nigerian economic features have been on the decline, following the sudden fall in the price of oil in the world market. This development has brought sharp focus or vulnerability of a mono-economy and subsequent attempt to demystify and/or diversify religion. The adjustment and other reform measures adopted by Nigerian government and her citizenry have compounded more problems rather than managing the fragile mono-economy. Consequently, myriad of social, economic, religious and political problems are being experienced today in Nigeria. This paper examines the religious values as a paradigm in the management of national economy in Nigeria. The paper first defined key words used in this presentation. Second, the paper makes and overview of national economy and the crises of development in Nigeria. Third, the paper discusses religious values and the management of national economy. Furthermore, the paper highlights the role of religious values as a paradigm of reform policy in Nigeria. Finally, the paper recommends among others, that rebuilding a virile, dynamic, egalitarian and robustly united Nigeria, must of necessity, entails institutional capacity building by way of restoring religious values that tend to strengthen the operation of our institutions in order to facilitate the task of genuine mobilisation for national development in all sectors of economy.
\end{abstract}

Key words: Religious, Values, Management, National, Economy and Reform policy

\section{Introduction}

As Williams (1980), rightly affirms, the mismanagement of national economy have made little or no progress in Nigeria. This, among things, derives from its uncritical neo-colonial policy of economy management. For quite some time, Nigeria economy was dependent on agricultural improvement in which capital intensive projects were planned and poorly implement. But with the discovery of oil in the 1970s, Nigeria economy was changed from agrarian economy to a mono-economy without modicum of industrial support. This fostered disarticulated and structurally incoherent economy that can hardly survive the periodic capitalist crisis in contemporary Nigerian society. The intense acrimony and antagonism that characterized Nigeria pattern of economic mismanagement has promoted dependent capitalism which laid no solid foundation for genuine economic strategy for national development but rather gross structural distortion in Nigeria economy. Though nobody can deny the fact that the main crisis in national economy is mismanagement by the post-colonial leadership, the dependence on the mono-economy has tended to create economy crisis in contemporary Nigerian society as other sectors are either totally abandoned by the government or are being slightly perturbed by it. It is the contention of the paper, that there is a dialectical correlation between, on the one hand, the biting economic mismanagement and the accompanying crisis of development, and on the other hand, the reformation agenda in Nigeria. The paper therefore, recommends, among others, that for Nigeria economy to receive a boast, a comprehensive frame work that will involve religious values and all the critical sectors of national economy such as education, health, housing and agriculture should be revived to enhance sustainable development in Nigeria.

\section{Conceptual Clarifications}

\section{Management}

The verb manage comes from the Italian maneggiare (to handle - especially tools), which in turn derives from the Latin manus (hand). The French word mesnagement (later ménagement) influenced the development in meaning of the English word management in the 17th and 18th centuries. Some definitions of management are: Organization and coordination of the activities of an enterprise in accordance with certain policies and in achievement of clearly defined objectives. Management is often included as a factor of production along with machines, materials, and money.

According to Gray (2000), management comprises the interlocking functions of formulating corporate policy and organizing, planning, controlling, and directing the firm's resources to achieve the policy's objectives. It involves organization and coordination of the activities of an enterprise in accordance with certain policies 
and in achievement of defined objective. Management consists of the interlocking functions of formulating corporate policy and organizing, planning, controlling, and directing an organization's resources to achieve the policy's objectives. Management in all business and organizational activities is the act of getting people together to accomplish desired goals and objectives using available resources efficiently and effectively.

In profit work, management has as its primary function the satisfaction of a range of stakeholders. This typically involves making a profit (for the shareholders), creating valued products at a reasonable cost (for customers), and providing rewarding employment opportunities (for employees). In non-profit management, add the importance of keeping the faith of donors. In most models of management/ governance, shareholders vote for the board of directors, and the board then hires senior management. Some organizations have experimented with other methods (such as employee-voting models) of selecting or reviewing managers; but this occurs only very rarely. In the public sector of countries constituted as representatives democracies, voters elect politicians to public office. Such politicians hire many managers and administrators, and in some countries like the United States political appointees lose their jobs on the election of a new president/governor/mayor. Thus, mismanagement in the context of this paper simply refers to disorganization and incardination of the activities of an enterprise in accordance with the policies of the government in achieving national economic goals.

\section{An Overview of National Economy and the Crisis of Management in Nigerian Development}

Since independence, of Nigerian economy has manifested crisis of varying kinds due to mismanagement by post-colonial leadership. This crisis can be divided into three main periods: the pre-colonial period, post-colonial period and the modern period of Nigeria's Economy crisis of management and Development in Nigeria. Each of these periods has its own crisis of management and economic development.

\section{The Pre-Colonial Period}

The pre-colonial period of Nigeria's economy development was dominated by British imperialist for several years and later became inextricably incorporated into the world capitalist economy with the assigned subservient role of primary commodities producer. The quest for cheap source of labour, congenial investment climate, viable markets for the excess goods produced in Europe, the burning desire to acquire raw materials and a host of others, were the motivating factors for such penetration and domination.

The phenomenon of industrial revolution amply characterized by mass production of industrial revolution undoubtedly triggered off the rush for colonies by the dominant European powers. The overriding objective of the British imperialist in Nigeria was however, to ensure the everlasting dependence of the country on the metropolitan economy. To this end, overwhelming emphasis was placed on agriculture with bias in the production of cash crops like cotton, groundnut, cocoa, palm oil, rubber and so forth to guarantee uninterrupted supply of raw materials to the industries at home, and to encourage the consumption of goods manufactured by the metropolitan industries.

Thus, conservable amount of resources were committed to strengthening regional dominance to undermine the national resolve and to lay solid foundation for genuine economic development. These regionalist proclivities of the post-independence politicians derived essentially in part, from the uneven pattern of development that was prompted by the British colonialists. The British economic interest dictated that only those areas with considerable agricultural and commercial potentials should be developed, thereby deepening the agony of the less resourceful ones.

However, the uncritical acceptance of the capitalist strategy of economic development bequeathed to Nigeria by the withdrawing colonialists promoted what is commonly referred to in the literature as "dependent capitalism". While the multinational corporations were busy extracting agricultural and mineral resources in the country, some commercially minded Nigerians were enthusiastically marketing manufactured goods imported into the economy by some of this foreign concern. So patently exploitative were some multinational corporations that most people perceived the British firms which pioneered Nigeria's colonization as largely "trading concerns which were primarily interested in collecting whatever Nigeria had and shipped them overseas, and importing consumer manufactured goods from Britain for sales in Nigeria" (Amechi, 1987).

The lack of sustained determination by the British to lay solid foundation for the industrialisation of the Nigerian economy rendered a heavily import dependent at independence. The quest for economic development in the country led to the adoption of import substitution industrialisation strategy of lat Sir Abubakar Tafawa Balewa. It was thought that this strategy would save enough foreign exchange when foreign concerns were encouraged to manufacture those essential items locally. One very glaring inadequacy of this strategy as conceived by the government of such manufacturing concerns on foreign inputs if they must sustain production at optimal level. Moreso, the prevailing socio-economic and political atmosphere then was hardly congenial enough to encourage such local production concerns.

This explains the lack of articulate and systematic policy of industrialisation which promoted what Ake (1981), refers to as "disarticulated" and "incoherent" economy. In other words, the British imperialist 
bequeathed to Nigeria at independence, an economy that lacked regional complementarily, reciprocity and linkages. This inevitably led to the emergence of a mono-economy with heavy emphasis on agriculture. Thus, agriculture contributed up to $66 \%$ of the gross domestic product, which later declined to $23 \%$ in the 1974 and to $18.4 \%$ by 1979 . However, the agricultural sector did not received substantial boast as peasant farmers were neglected in the country side, and there was no concerted or sustained efforts by the post-colonial Nigerian leadership to boast agricultural activities because of the intense acrimony and antagonism that characterized the country's pattern of economic management as earlier stated. Thus, the discovery of oil after the Nigeria, civil War in the 1970s, took over the position of agriculture by emerging not only as the dominant source of national income and foreign exchange, but also that of national capitalist development, accumulation, formation of new social classes and contradictions in the Nigerian society (Beckman, 1981).

\section{The Post-Colonial Period}

The post-colonial period of Nigerian economy development is often referred to as the starting point of Nigeria's economic crisis. The discovery of oil in commercial quantity brought into sharp focus, the origin and dynamics of the contemporary Nigerian economy crisis, the oil boom of the 1970s under the military government of General Yakubu Gowon abruptly swerved the Nigerian economy from a productive one to a consumptive one largely characterised by the progressive neglect of the agricultural sector in favour of the oil sector due in large part, to the enormous foreign exchange derived from the sector.

Thus, the agricultural sector kept stagnating instead of being modernised to complement the oil sector in foreign exchange earnings. However, with the emergency of oil as the chief revenue earner, the country started experiencing a distorted transition from an economy transitionally based on the agriculture to one precariously on petroleum (Newswatch, 1993). The immediate and practical effect of this abrupt and tragic shift was the unprecedented mass exodus of people from rural formations traditionally noted for agrarian activities to urban area in search of jobs, thereby leaving behind aged population that cannot effectively cope with the arduous task of primary production activities (Olayide, (ed.), 1976).

This development had obvious negative implications for the economy as it brought about the sharp distortion in the economy because agriculture until 1973, provided employment for over three quarters of the Nigerian population, with the oil sector, having only 6,000 workers (Newswatch, 1993). The consequence of this gross structural distortion in the economy was the inevitable shift from being a leading exporter to net importer of food. The country's food bill amounted to $\neq 1.106$ million in 1979 (Mai-Lafia, 1997). This figure rose to $\neq 1.5$ billion in 1980 , and in 1981, importation of rice alone consumed about $\neq 463$ million (Imobigh, 1986). The enormity of the resources committed to importation of food to feed the teeming populace in a dependent capitalist commotion was clearly suggestive of the imminent crisis the economy was soon to run into.

Two military regimes came to power after the General Gowon regime. First, was Major General Murtala Mohammed (1975) whose administration was terminated shortly afterwards by another coup d'etat which brought Major General Obasanjo to power. During Obasanjo military government, Nigeria's economy began to show signs of recession, as was seen in the budget of 1979 and 1980 (New Nigerian, $3^{\text {rd }}$ April, 1979), indicating the general poor performance of the economy. Nigerians accused General Obasanjo's regime of diverting Nigeria's money to the tune of $\neq 2.8$ billion to private foreign account. The oil revenue and market began to drastically dwindle. This can be seen from the Federal Government revenue in 1976 and 1977, which was about $\$ 30$ billion dollars, but fell to $\$ 63$ billion in 1977/1978 and to $\$ 5.2$ billion in 1977 to $\$ .6$ billion in 1978. During the same year, the contribution of petroleum to national total production output declined by 10 percent (Mai-Lafia, 1992). The national deficit rose from $\neq 656$ million in 1977 to $\neq 2.3$ billion in 1978. So was the percentage of the national income used to service foreign debt which grew from $0.3 \%$ in 1977 to $8.9 \%$ in 1982.

There is no doubt about the fact that the beginning of the Nigerian economic mismanagement and crisis of development started during the military regime of Obasanjo, when he indebted the country from $\neq 496.9$ million in 1976 to over $\neq 2$ billion in 1978 (Mai-Lafia, 1992). General Obasanjo took 32 billion Naira "Jumbo" loans from the International Capital Market (ICM). This single loan altered the structure of Nigeria's debt which hitherto comprised of soft concessionary loans from the World Bank and other sources. Federal and State authorities, "dark with loan elixir, burst in out of ICM stuffed with loans they had little knowledge of how to repay it" (The Nigerian Economist, May 7, 1989).

To meet the conditionality of the loan capital, however, General Obasanjo announced his "austerity measures" in the form of budgetary, fiscal and monetary controls like the harsh income guidelines, new credit lines, new uniform, tax law and permanent wage freeze which were all announced in 1978 and 1979. Some luxury export goods were banned, staff from Grade Level 07 and above had their annual salary increases stopped. The austerity measures essentially touched on welfare and state public services like the withdrawal of petroleum subsidy, vehicle loans, motor basic allowances and introduction of school and hospital fees in government owned schools and hospitals. These measures which were clearly aimed at satisfying the 
conditions of foreign capitalist accumulation in Nigeria inevitably sparked off reactions from university students, industrial workers, journalists, and all the democratic forces in the country (Mai-Lafia, 1992).

The state as expected intervened directly to express the demonstrators and the Nigerian security Organisation (NSO) was set up. Demonstrating students of the Ahmadu Bello University (ABU) and Lagos University (Uni Lag) were short in 1978. Some lecturers alleged to be radicals and behind the students were dismissed in the University of Ibadan. The National Students Union body (NANS) was banned, while many trade unions leaders, workers and journalists were detained or sacked from their jobs. The state intervened directly in the national labour body by reorganising it from 896 existing registered scattered union to 70 unions under the central control of the Nigerian labour Congress (NLC), for state's easy manipulation.

\section{The Modern Period}

The modern period of Nigeria's national economy crisis and development became deeper in 1988 when the crisis took a gloomier look as the country sinks into the world of recession. The revenue of the state began decline progressively, especially in the oil revenue as could be seen in its fall from about $\$ 38$ billion in 1980 to less than $\$ 5$ billion by 1984 (UBA Monthly Business and Economic Digest, September, 1989). The implication of this to the decline of capital and welfare projects for the people is quite obvious. The Nigerian foreign debt rose up during this period from $\neq 1.2$ billion in 1977 to over $\neq 150$ billion in 1989. So was the debt servicing, which jumped from 1 percent of the country's income to about $50 \%$. Budget deflects also rose from $\neq 2.6$ billion in 1978 to $\neq 12.4$ billion in 1988. The trend in the growth of Nigeria's external debt outstanding and debt service Table I below, indicates how the huge country's earnings that could be used to finance socio-economic development in Nigeria are being diverted to pay up and service foreign debt.

Table I: External Debt outstanding and Total Debt Service 1971-1987 Total Debt Outstanding Value of Export Total Debt Service Debt Service Ratio

\begin{tabular}{lccccc} 
& N'million & \$'million & N'million & N'million & $\%$ \\
\hline 1971 & 214.5 & 308.9 & $1,293.4$ & 29.9 & 2.3 \\
1972 & 263.4 & 400.4 & $2,434.2$ & 26.2 & 2.8 \\
1973 & 276.9 & 420.9 & $2,369.2$ & 30.8 & 1.3 \\
1974 & 322.4 & 523.3 & $5,794.0$ & 29.1 & 0.5 \\
1975 & 349.9 & -559.2 & $-4,925.5$ & 32.7 & 0.7 \\
1976 & 374.6 & 593.6 & $6,709.8$ & 34.4 & 0.5 \\
1977 & 496.6 & 762.9 & $7,630.7$ & 25.6 & 0.3 \\
1978 & $1,265.9$ & $2,163.8$ & $6,064.4$ & 160.8 & 2.7 \\
1979 & $1,611.5$ & $2,824.6$ & $10,836.8$ & 182.9 & 1.7 \\
1980 & $1,866.8$ & $3,444.8$ & $14,077.0$ & 101.6 & 0.7 \\
1981 & $2,331.2$ & $3,667.7$ & $10,470.1$ & 518.6 & 5.0 \\
1982 & $8,819.4$ & 13.124 .1 & $8,722.5$ & 775.2 & 8.9 \\
1983 & $10,577.7$ & $14,130.7$ & $7,502.5$ & $1,335.2$ & 17.8 \\
1984 & $14,536.6$ & $18,034.1$ & $9,088.0$ & $2,640.5$ & 29.1 \\
1985 & $17,290.6$ & $17,297.5$ & $11,214.8$ & $3,718.0$ & 33.2 \\
1986 & $42,229.5$ & $18,631.3$ & $8,513.0$ & $2,502.2$ & 29.4 \\
1987 & $86,550.8$ & $26,200.0$ & $30,239.9$ & $3,590.6$ & 11.9 \\
1988 & $146,410.0$ & $29,282.0$ & $27,101.7$ & $6,630.5$ & 30.0
\end{tabular}

Source: The Nigerian Economist, May 9-12 1989

The central point to note here is that the huge country's earnings was being diverted to pay up and service these foreign debts. It is estimated for example, that in the year 1990/1991 alone, the Federal Government in its budget allocated the sum of $\neq 39.7$ billion over $42 \%$ of its total annual expenditure just to pay interests on external debt. This massive amount, it has been calculated, "is equivalent to the whole of the 1990 allocation to the 21 state Governments and half of the total allocation to the Local Governments from the Federal Accounts" (Usman Bala, Guardian 21, January, 1990). And if not because of debt rescheduling the country would have spent over 89.5 percent of its total foreign exchange on debt servicing in 1989 (UBA Monthly Business and Economic Digest and capital of these debts, the country would have nothing whatsoever left even to finance its day-to-day activities.

This unwholesome development coupled with the brazen poverty culture of prudent spending by government made it increasing difficult for the Nigerian state to meet the basic essentials of her citizenry within the available means. Monumental corrupt practices through over invoicing of imports, kickbacks from contracts, outright looting of public treasury and above all the ravenously exploitative activities of the multinational corporations, accentuated the scope and magnitude of the looming crisis that was to besiege the Nigerian economy. One concurs with Heineckes (1986), on the point that:

Ruthless determination to get one's own way by any means and the insatiable obsession with material accumulation is the virtues of capitalism and they are also the sources of corruption in Nigeria. 
Thus, the period of leadership under Alhaji Shehu Shagari was largely characterized by rising inflation, hunger, prostitution, high crime rates, food insecurity, mounting foreign debts, mass unemployment, and so on (Julius, 1991). All these problems had reached alarming proportion, thereby posing credible threats to systematic stability and efficacy of Nigeria economy development. Faced with these daunting socio-economic and political problems, Alhaji Shagari had to resort to external borrowing which eventually catapulted the volume of Nigeria's external debt. The steady rise in the debt figure in the bid to meet the basic needs of the ordinary Nigerian citizenry continued to increase with a dramatic turn with sharp fall in the price of oil, resulting from oil glut in the world market. For instance, within four years of Shagari's administration, Nigeria borrowed $\$ 21$ billion dollars (Zuwaghu, 1986). Under this debilitating debt burden, the goal of development became very elusive as agonizing poverty was widespread. This necessarily rendered workers purchasing power important and the consequent decline in national productivity.

The persistence of problems of mounting debt burden, growing rate of unemployment, decline in living standard, mass hunger and poverty, balance of payment deficit, and so forth, compelled the government of Alhaji Shagari to adopt in April, 1982, the ineffective "austerity measures", through the economic stabilization (Temporary provision) Act. This Act sought to reduce government expenditure and curtail imports through massive imposition of import duties on goods brought from outside. In spite of the implementation of this Act, the crisis persisted. The Shehu Shagari considered the structural Adjustment option as solution to Nigeria's economics. Thus, he confessed in the national independence speech of October $1^{\text {st }} 1983$ that:

To review and stabilize the economy on a long term basis, it is imperative that the country now begins a structural readjustment process required for reviews economic buoyancy.

This statement was put in stronger terms on December, $19^{\text {th }} 1983$ in his test to address to National Assembly "given our present financial situation and the trend in demand for oil, it is clear that a structural adjustment of economy is imperative". The Shagari administration plan for the introduction of SAP was only cut short by the abrupt end that was to put to it by the 1983 coup d'etat. Thus, on the $31^{\text {st }}$ December, 1983 , the Buhari/idiagbom regime poignantly took over power. There was a great deal of hopes generated, particularly among most affected workers who had the growing expectation that the military government under his regime was, in accordance with military tradition, going to turn things for the better.

However, faced with the enormity of crisis it inherited from the ousted civilian regime, the Buhari regime adopted a two pronged approach to them. The first was political and was essentially to intimidate and silent those perceived as hostile antagonistic to the policies of the new regime. Draconian decrees such as the notorious security decree No. 2 were churned out to clamp down massively on trade unions and other interest groups. The swift and ruthless application of this decree bred a general atmosphere of fear and insecurity in the country. Paradoxically, this measure rather than mitigating the intensity of sustained opposition to the policies of the regime did heighten the wave of general antagonism in the country. The adoption and implementation of the policy of War against Indiscipline (WAI) by the regime which was intended to sanitise the muddled system was widely perceived as anti-people. Although there was need to have in place such a policy in order to socialize people into the culture of moral rectitude and orderly behaviour, the aggressiveness with which it was prosecuted could not but generate ill-feeling among the populace (Zuwaghu, 1986).

The second approach which was economic was largely characterised by dogged commitment of the regime to Structural Adjustment measures. Thus, at his world press conference on January $5^{\text {th }}, 1984$, General Buhari began to make known his economic recovery intention "in the medium and long term we intend restructure the economy in order to increase our resource base internally and externally". He also mentioned this in an address at the Nigerian Institute for social and Economic Research (NISER) in Ibadan, November $26^{\text {th }}$, 1984.

...because of the structural adjustment required to place the economy on the path to early recovery and selfsustained growth, the present administration has decided against any extension of the life of the Fourth plan.

The regime backed its utterances with action on this subject. The monetarist policies perquisite for the IMF/World Bank adjustment loan started being implemented with vigour. The administration introduced some monetarist measures like aggressive repayment of external debts: mass retrenchment of able-bodied workers; substantial cut in budgetary allocation to ministries and parastatals, complete embargo on employment massive wage and salary cuts, appreciable reduction in government expenditure, massive devaluation of the naira and extensive trade liberalisation among others (Iyoha, 1992). But the regime saw the need to exercise caution on the issues like removal of subsidy from petroleum and related products, devaluation of the naira and trade liberalization on the grounds that these were rather harsh and would mean opening Nigerian gates to all types of imported goods.

Major General Idiabon highlighted this in his address to members of the Nigerian Political Science Association on $18^{\text {th }}$ May, 1985 in Ilorin. The disposition of Buhari regime to the political and economic measures aimed at resolving the crises, accentuated the plight of the masses who felt frustrated and alienated from the government because of the introduction of new taxes, levies, fees among others. It is worth nothing that 
a government that generates intense feeling of alienation and frustration among its citizenry can hardly enjoy their support and cooperation. This provided the immediate contact for a counter coup which eventually installed General Ibrahim Babangida as the president and commander-in-chief of the Armed Forces of the Federal Republic of Nigeria.

The immediate challenge before the military government of President Babangida was the persistent economic crisis which seemed to have defied practical solution. Realising the widespread resentment of the stringent policies pursued by Buhari/Idiagbon regime, Babangida though it was wise to deviate a little from the typical military tradition in order to avoid the social disabilities that characterised his predecessor, the regime initially adopted democratic approach to finding lasting solutions to the multiple socio-economic and political problems. For instance, the regime created diversions through debates on such national issues as the IMF loan and the political future of the country. However as usual, such a false democratic outlook towards national issues was more of an instrument to mobilise support and loyalty for the purposes of power consolidation rather than genuine search for a viable and productive ideas towards resolving the looming crises (Amechi, 1987).

As one would expect, after having sufficiently consolidated itself in power with substantial aura of legitimacy, the regime in a dramatic turn and to the chagrin of most Nigerians, became unbelievably antagonistic to the very ideal it professed initially. The regime with dogged determination and rapidity hitherto unthought-of, articulated its economic policies which were largely predicated on the monetarist framework. The economic policy framework was the Structural Adjustment Programme (SAP) adopted on the $27^{\text {th }}$ of June, 1986 which was emphatically and overwhelming opposed by the people in the course of the IMF loan debate. This IMF inspired SAP which was masqueraded as Nigeria's designed policy response to the economic crisis was initially meant to last for two years (July $1^{\text {st }} 986-\mathrm{June} 30^{\text {th }}, 1988$ ). Indeed, it was another conscious attempt by the regime to allay the widespread fear associated with the perceived excruciating impact of the policy (Zuwaghu, 1986).

The policy of SAP was meant to address certain perennial problems of the Nigerian economy such as excessive dependence on oil, chronic lack of self-reliant growth and development, persistent balance of payment disequilibrium, growing budget deficits, growing decline in productivity, persistent inflationary trend, etc. (Gini, 1992). The policy of SAP was said to be crucial because of the general perception that the Nigerian state was heavily loaded and this has tended to undermine the efficacy of the state in playing developmental roles. Instead of relieving the state of the heavy burden imposed on her, the policy of SAP has made Nigeria to grapple with the task of how to avert running into a state of inertia due to growing demands made upon it by the populace.

People have hardly appreciated the policy of SAP as a corrective measure but more as a sharp aberration from the tradition of a caring and protective state. Wide consensus seems to be crystallizing behind the view that rebuilding the health and strength of the Nigerian economy must begin with diversifying sources of foreign exchange earnings by paying overwhelming attention to agricultural production (Akindele, 1993). The Nigerian State under the military has hardly demonstrated concerted and sustained efforts to rebuild the moral values of the society without which recovery would be almost impossible. It is believed by many observers of the Nigerian political economy that if the proceeds realised through the commercialization and privatisation policies were frugally and prudently managed, the magnitude of our crisis would not have assumed this consuming proportion.

The brazen display of corrupt proclivities by government officials derives essentially from the fact that moral values have been eroded in Nigeria under the military. This cankerworm had reached its pinnacle under the bankrupt leadership of the former president Babangida who institutionalised corruption as a virtue in the society when he needed desperately to sustain himself in power in the face of wide resentment. Instead of strengthening the values of honesty, transparency, accountability, integrity and frugality in the management of the affairs of the state, the General was actively undermining these values which perhaps would have bolstered up the legitimacy of the regime and his wide popularity. Given the profound crisis the economy is engulfed in, it cannot but prove unresponsive to the growing needs and aspirations of the citizenry and this has considerable potential for eroding the sense of Patriotism and loyalty of the populace to the system (Mai-Lafia, 1997).

The debitability economic situation of Nigeria did not improved even under Sani Abacha whose administration was shortly terminated by his death, and Shonikon was appointed the interim head of states and commander-in-chief of the Nigerian Armed Forces. As the Nigeria economic crisis deepened further Brigadier Sani Abacha aptly summed up the existing socio-economic realities of Nigeria at that time thus:

I am referring to the harsh intolerable conditions under which we are now living. Our economy has been hopelessly mismanaged. We have become a debtor and beggar nation. There is inadequacy of food at reasonable prices for our people. Health services are in shambles as our hospitals are reduced to mere consulting clinics, without drugs, water, and equipment. Our educational system is deteriorating at an alarming rate. Unemployment figures including the graduates have reached embarrassing and unacceptable proportions. In some states, workers are being owed salary arrears of eight to twelve months (The Guardian $2^{\text {nd }}$ Jan. 1984). 
This was the economic situation of Nigeria during the Second Republic when the military stepped into save the situation. It is quite a wholesome development that the military who are supposed to be the custodians of national values by their claim to Puritanism, have become the very pollutant in Nigeria today. It is hardly contested that corruption has been the dominant feature of military rule particularly under the former president Babangida. Nigeria at present lacks a credible and dependable military formation to guarantee both its internal and external security (Abba, 1985). This ugly situation of Nigeria economic mismanagement of both military and civilian leaders is suggestive of the role of religious values in transforming the Nigerian economic policy in contemporary time.

\section{Religious Values in the Management of Nigeria National Economy}

In practically every known religious tradition values give distinct personality in transforming, rebranding and reforming people and policies. These values which includes honesty, fear of God, accountability, fair play, justice, solidarity spirit, patriotism spirit, peace, harmonious living, among others are fundamental for development of the religious society. All religion's founders and thinkers recognized these religious values as constitutive of the belief system. They are indisputably attached to the problem of religion and society and Nigeria is by no means an exception to this rule. It is therefore, pertinent to submit this discusses on Nigeria, a nation with over two hundred linguistic groups who are notoriously religious and where three major religions: African Traditional Religion, Islam and Christianity thrive side by side, in worrisome conceptual relationships.

Thus, in Nigerian society there are ethical codes with spiritual values in the three major religions which guide and defend jealously the moral teachings in the society. For example, in African traditional religion, it is the traditional customs, the equivalent of mores in scholastic theological manuals. For the Muslims, it is the Hadith, in the Judeo-Christian tradition, it is the Decalogue reinterpreted as Love-Ethic in the New Testament. Every one of Nigeria's religious traditions protects its own codes in order to ensure that values of discipline, moral rectitude and life are preserved in society. Besides, these religions are succeeding in generating meaningful sense of the sacred in inspiring social solidarity and mutual co-operation and in sensitizing both the young and old citizens to cultivating devotions to abiding moral principles.

The religious values are legacies of our religions bequeathed to adherents for the development of Nigerian society. They promote morality which is another religious value that is highly valued by all people and it served as the bedrock of the education for children as they grow up (Banguru, 1995). Morality helps those chosen for the position of leadership or placed in charge of various institutions to be accountable to the constitute authority, thereby making them good leaders. Bako (1986), affirms this fact thus:

A good leader must be culturally, socially, psychologically, intellectually and spiritually mature. $\mathrm{He}$ must also be an honest who is truthful and willing to say the truth without fear of intimidation or favor. He gives to everybody what he/she is supposed to have without prejudice, and maintain cordial relationship with the neighbor are religious moral values held in high esteem by Nigerians. He also disciplined because a disciplined life is one of the most cherished religious values that is lacking today.

(Akwang, 2008) Mazui (1980), further states that it is the religious value that promote cultural, religious, political and socio-economic development of any nation in the world. However, indiscipline individual's political landscape are being rewarded today with juicy appointments and elected or picked to represent their people or constituencies which they do not merit. Thus, religious values such as hospitality, solidarity spirit, fear of God, justice, accountability harmonious co-existence and patriotism have been regrettably neglected in Nigeria today among adherents of various religious groups. Hospitality for example, is a duty expected of every member of religion but it has been neglected in contemporary Nigerian society (Gana (2007). Mbiti (1969), Maquet (1972), Egbuna (1973), and Nkrumah (1975), concurred that in Nigeria leaders are only concern with what matters to them and not the society as a whole. They compromised commitment, dedication and concerted efforts for the sake of progress and development of the society.

Honesty and accountability which were religious values highly cherished in pre-independence Nigerian society are thrown into the dustbin. In all endeavors, absolute value for right at home, in business practice and leadership are compromised. It is only the honest few persons that can give account of the privilege responsibilities given to them. Many Nigerians fined difficult to give honest and satisfactory accounts of their stewardships. This means that bribery and corruption have been legalized in high places because they know their way out of "nemesis". That is why they always find their way with every government (Gana, 2007). Hard work is no longer rewarded but instead those who proved to be industrious are severely dealt with. Corrupt individuals now acquire wealth to frustrate and intimidate the hard working class instead of motivating those who are lazy to put extra efforts in their works Ushe (2007).

The consciousness of the ultimate or Supreme Being or God, is no longer imbued in the lives and hearts of Nigerian people. Thus, they commit all kinds of atrocities such as cheating, stealing, sexual promiscuity like homosexuality, transgenderism, and lesbianism which are opposed to universal accepted standard of religious values in Nigerian society. The religious value of patriotism is meant to teach all religious 
adherents in Nigeria to be loyal to the community or nation to which they belong, support the law enforcement agencies in enhancing national development and by encouraging every member of Nigerian society to participate in the political process to enhance national development. As George Aluko (1996), the president of America in his farewell Address in 1796 noted:

Popular government cannot exist without morality and morality is based upon Biblical and a traditional principle...The best government is the one that is self-government, not self-indulgence.

The point George Washington is making here is that in underdeveloped nation like Nigeria, the dream of patriotism is hardly realizable. The adoption of a political system that does not aligned with the socioeconomic realities of the Nigerian people is bound to create a problem which could results into a conflict of interests between the different paradigms of the society and convoluted ideas, thereby making the religious values and economic system to act antagonistically to each other. Nigeria has failed this so called litmus test when it comes to patriotism, political correctness, religious sanctimony and economic ideologies.

As Nigerians we are playing the game of "catch up", and by the look of things we can never catch up because Nigerian nation have long since abandoned their moral fabric, which held them together for so long in pursuit of a more "modern" and "acceptable" way of governance. It is time Nigerian leaders must work up and smell the coffee otherwise, the masses themselves will be held at ransom with the arm twisting tactics that characterize "foreign aid" policies of the so called first world nations. It is true that some African nations such as Malaysia, Ghana, among others, managed to hold onto their religious values and to shun the existence western values of the so called developed cultures, yet still they are able to westernize their ways of doing things. They are dynamic enough to adopt the desirable policies of the progressive or first world states that are totally foreign to them.

The painful truth is that, this is an epitome of Nigerian nation who has become foreigner to its customs. We have a Nigerian saying that "new developments have to be built on top of existing ones", which means that Nigerian nation can only developed by borrowing a leaf from the developed nations of the world. We do not have to uproot everything to start from scratch, just because we want perfection. But we need to follow the footsteps of developed nations such as China, South Korea and other Eastern Asia nations who despite their levels of developments, still cling onto their religious values for national developments.

These religious values which dominate developed nations of the world can be infused into the modern leadership style of Nigeria like those of other nations for meaningful economic development. It is only when this infusion is achieved that we can talk of national economic development in Nigeria. When such religious values becomes central to the management of the society and the people imbibed them, then vices such as corruption, gross inequality, injustice, lack of accountability, dishonesty and untruthfulness in the distribution of wealth can be eradicated in Nigerian society. It will also permit one to lift the nation to its true direction and potential of economic reconstruction and reformation in contemporary Nigerian society.

In spite of the rumour of success in economic growth, Nigeria is confronted with the big question that hung's the minds of many thinkers: Can the religious values practiced by the three religions in Nigeria contribute anything towards the quest for authentic values which compromise good management, tolerance, trust, honesty, accountability, bear of God, spirit of patriotism, peace and mutual co-existence to advance the cause of economic growth and democratic governance? Kalu (1987), provided a prophetic answer to this urgent pertinent question. He observes:

Islam and Christianity have made large particularist claims of being "the way of life" worth aspiring. Yet they need to be "relevant" amidst beclouding secularism and the forces of persistent indigenous religions. The nation must strive before they could or otherwise the adherents may have to go home to heaven.

Kalu's answer sound prophetical because his oracle does not reflect a melancholic perusal of the signs of the times on the Nigerian socio-religious condition. If the values Nigeria's religions cherish are to be merely trans-historical, the nation would be doomed forever, and that would amount to a pietistic attitude in religion which Max Weber resented in the German Youth close after the world war I. Also, the elders who composed the second Epistle of John noted that such values were irreligious when he indicated his readership in the words:

Ho gar me agapon too adelphon autou hon heōraken, ton Theon hon ouk heōraken ou dunatai agapan, which means "He who does not love his brother whom he has seen, cannot love God whom he has not seen" (I John 4:20).

Besides, this excursus on the relativity of values, its place in the body of knowledge in traditional religion and its teaching in Islam and in Christianity cannot be underestimated. In both traditions, due emphasis is placed on values through the process of refining and enhancing the natural dispositions of man. The first verse of the Qur'an reads:

Recite in the name of your Lord who created, created man from clots cloud. Recite! Your Lord is the most Bountiful One, who by the pen taught man what he did not know. 
Here is a quranic injunction to the Holy Prophet and to his followers. It is a call to allow enlightment take over the place of ignorance. The text draws attention towards the value of education and learning. Indeed, the search for knowledge and the values attached to it is a religious obligation for every committed Muslim, research in the history of religions shows that Islam did not come to destroy the prescriptions of Judaism and Christianity, the two proceeding religions. Thus, Islam and Christianity should encourage the persistence of a moral code conduct which promotes the value of self-persistent; compassion and equity. Majasan (1976), emphasizing this needs of moral code in Nigerian society states:

... growing boys and girls must themselves be properly educated because of their role as fathers and mothers in the life of the tribe. The basis for courting, use of language, knowledge of the customs and traditions is laid during this period. The young father and mother is supposed to be the inexperienced class teacher and the maternal grandfather and grandmother, the headmaster and headmistress of the small domestic kinder gotten.

\section{The Role of Religious Values in Reforming the Management of Nigerian National} Economy

For the management of Nigerian national economy to experienced a positive development, religious values such as fear of God, honesty, accountability, social justice and a host of others must be imbibed by the citizenry. No meaningful transformation can occur in the economic growth of Nigeria as a nation unless the ideologies, thought patterns and lives of the individuals are rebranded. It is a pity that Nigeria is yet to experience rebranding in every sector of the society. Nigerian society has seriously been visited by changeagents associated with the advent of Islamic and Christian religions, which for many have precipitated an inroad in trading economic growth. While a few have achieve a marked increase in economic gains, the majority of Nigerian people have been subjected deeper poverty due to exploitation, corruption, injustice, lack of accountability, no fear of God and bad governance. This has not only raised question on the dignity of Nigerian person but also affirmed the necessity of transforming the economy on Nigeria in modern times.

For economic development to thrive, Nigerian leaders must become aware of the need to emphasize certain values such as honesty, transparency, fair play, self-respect, human dignity and rights, people's participation in decision making, equal opportunities for all and common actions against dehumanizing agent or institutions and creation of more jobs opportunities. It is only when this situation is curbed, especially as we march the feet's of democratic dispensation then shall the marginalization of the Nigerian masses from political and economic mainstream and their increasing powerlessness will be destroyed. The Churches and Mosques in Nigeria must strive to preach religious values that help in sustaining national economic development in contemporary society. The lamentation of the Catholic Bishops conference of Nigeria $(\mathrm{CBCN})$, pictures this state of affirms thus:

But how can economic development, religious values and peace thrive in the midst of discord and allpervading religious conflicts, fanaticism and terrorism? How can the voice of truth be heard in the deafening noise of lies and deceit? How is injustice to be achieved where the few rich and powerful are squeezing the very life out of the vast multitudes of our poor and powerless people? Has religion anything to say? Has it anything meaningful too proposed? Have religious leaders any role to play? Have they anything meaningful and effective to contribute? Where is the light to guide the nation? Where is the power to save the oppressed? (Onaiyekan, 1989).

The lamentation of Catholic Bishops Conference of Nigeria $(\mathrm{CBCN})$, above is a clarion call and challenge to adherents of both Islamic, Christianity and African traditional religion, the three main religions professed by over $95 \%$ of the Nigerian population. To combat injustice and wrong-doing in Nigerian society, therefore, adherents of these religions (ATR, Islam and Christianity), must come to recognize the need for collaboration. Religious differences demand talking, not fighting, adherents of all religions must come to recognize that economic growth in religious society involves conscientious knowledge, hard work, moral behaviours and willingness to co-operate with others. Luke, the evangelist has put it poignantly in this way:

Ouk estin prosopolempties ho Theos, all en panti ethnei ho phobomenos auton kai ergazomenos dikaiosumen dektos auto estin, which means "God shows no partiality, but in every nation anyone who fears him and does what is right is acceptable to him" (Acts 10: 34-36).

In the traditions of all religions, therefore, the mission is to promote a right order of values in human affairs for sustainable development of national economy, and Nigeria is not an exception in this regards.

\section{Conclusion and Recommendations}

From the foregoing discussion it is clearly seen that the responsive and distributive capacities of any system are the two critical and silent ingredients that determine the efficacy and viability of that system. Thus, in the 1970s, Nigeria could boast of pursuing vibrant and assertive foreign policy goals simply because of the buoyant and redoubtable character of the economy (Courtesy of oil boom), but the same can hardly be said of the nation's foreign policy today. However, with unfolding of economic realities, it became necessary to thinker 
with the structure of economy with a view to adopting a policy that would encourage diversification in order to restore its resilient character that was the hallmark in the boom days. This led to the adoption and implementation of the policy of SAP towards this end and has generated a deep crisis of governance owing to the neglect of a crucially vital counterpart of SAP which is the moral values reconstruction. It is a widely shared perception that whatever might be the gains of SAP, the positive impact is hardly fact by Nigerians. It has rather exposed Nigerians to crippling and agonizing economic hardship.

It is our considered opinion that rebuilding a virile, dynamic, egalitarian and robustly united Nigerian economy, must of necessity, entail institutional capacity building by way of restoring religious values that tend to strengthen the operation of our institutions. In this, wise, ethics like honesty, accountability, transparency, integrity, committal to social justice, fairness, equality and mutual respect can, if well put in place, restore lost confidence and hope as they facilitate the task of genuine mobilization for national development. The military factor has been addressed but needs to be put in its rightful perspective if the nation must move forward. The uphill task before Nigerians now is to rehabilitate the military in a way that any attempt to strive back would hardly be successful. As Nancy (1997), rightly observed:

The mismanagement of Nigerian economy by the military regimes and the civilian regime of Shehu Shagari precipitated the inroad for abject poverty, moral decadence, bribery and corruption, injustice, the rule of law, lack of accountability, dishonesty and religious manipulations for political gain in Nigeria. Bribery and corruption threatened to consume the people with government appointments, public service workers, even the rulers themselves, as well as the nation's law enforcement agents being caught up in the web. The brazen display of corrupt proclivities by government officials derives essentially from the fact moral values have been eroded in Nigeria. This cankerworm had reached its pinnacle under the bankrupt leaders of president Babbangida who institutionalised corruption as a virtue in the society when he needed desperately to sustain himself in power in the face of resentment.

This prevalence situation amply illustrates the mertonian condition of anomie in the management of Nigeria national economy which characterised non-conformity with accepted religious values in the society as noted in the political Bureau Report (MAMSER) of 1987. In its explanation:

Corruption and indiscipline are two of the most serious problems which have confronted the Nigerian economic process since independence. Nigerians are indeed unanimous in believing that any effort at erecting economic order which does not take into consideration the problem of reform agenda...is bound to fail. Any country where brazen insensitivity, arrogant selfishness and corruption lay claim to leadership and educational system or where the ordinary people put up with such arrant nonsense is bound to experienced economic mismanagement and crisis in the development (MAMSER, 1987).

Nigerian cannot hope to move forward as a nation unless the religious values which have been ridicule over the years by the various regimes must be accepted and transformed through the help of religious tenets. This reformation policy will not only involved the government but also include a reasonable population of Nigerian citizenry who shared in the belief of the nation. Given the above facts, the paper proffers the following recommendations to the government and people in Nigeria:

1. Government must encourage other sectors of economy such as agriculture, fishing, mining, rather than depending on one economy (crude oil) for rational development.

2. Government and religious institutions must work together to rebrand Nigerian citizenry against corrupt practices that hinder economic development in Nigeria.

3. All the three major religions in Nigeria (ATR, Islam and Christianity) must thrive hard to promote religious values in the society.

4. Religious leaders of the three religions in the country must seek ways and means to forge forums for mutual understanding, collaboration and dialogue independent of government interference and political manipulation.

The road to our national great mess must be paved with justice, accountability, honesty, fair play, fear of God, patriotism, solidarity spirit, and peace. Our nationals who have strong faith in God and Allah should strengthen their love and faithfulness to God and prove to unbelievers that religions have positive roles to play in the struggle for the establishment of authentic religious values for the development of economy in Nigeria.

\section{References}

[1] Abba, A. etal (1995), Nigerian Economic Crisis Causes and Solution. Zaria: Assu.

[2] Abdulkadir, M.S (92008), Globalization, Poverty and Youth Unemployment in Nigeria. "Being a paper presented at the International Conference on Nigerian Youth and National Development", Organized by the Centre for Democratic Research and Training. Mambay a House, Kano Nigeria, August, $5^{\text {th }}-6^{\text {th }}$.

[3] Adegbesan, P. (1987). "Pragmatic Involvement in Religious matter: A Case Study of Nigeria", Nigerian Journal of Theology, Vol.1, No.4.

[4] Akeredolu, A.E.O., (1975), The underdevelopment of Indigenous Entrepreneurship in Nig. Ibadan University Press.

[5] Akwang, M. (2008), "Human Trafficking as Hindrance to Effective Economic Revamp in Nigeria". A Paper presented at the 5 annual conference of the National Association of Science Humanities and Education Research (NASHER). 
[6] Aluaigba, M.T. (2006), "National Corporation and the National Development: An Insight from the Nigerian Oil Sector", FAIS Journal of Humanities, Vol. 3.No.4, BUK, Kano

[7] Aluko, S.A. (1996), "Guided Deregulation and the Nigerian Economy", A Convention Lecture delivered at the Graduation Ceremony of Bayero University, Kano $22^{\text {nd }}$ November

[8] Ake, C. (19981), Political Economy of Africa: Longman Group, Lagos.

[9] Ake, C. (19981), Political Economy of Crisis and Underdevelopment in Africa: Juliuus Ihonvbere ed.) Selected Works of Claud Ake

[10] Akindele, R.A. (1993), 'Managing Nigeria: Reflections and Prescriptions' in Annals of the Social Science Council of Nigeria.

[11] Amechi, K. (1987), Foreign Capital in Nigeria: Roots of Under Development. Lagos, Heartland publishing House.

[12] Baby, A.M. (1988), "Anti-SAP Movement in Africa”. African Concord, Dec, Aug. 14

[13] Balogun, O. (1988), "SAP's Asterisk of Doubt", Afriican Concord Sep. 12

[14] Bako, S. (1986), "Economic and Intellectual Crisis: A critique of Abba, et al. The Nigerian Economic Crisis: Causes and Solutions. Zaria Department mental seminar, political science, ahmadu Bello University.

[15] Business, (1987), Concord, Dec. 19

[16] Banguru, Y. (1995), "Adjustment, Authoritarianism and Decracy: An Introduction to Some Conceptual and Empirical Issues", in Thandika, M. and Adebayo, O. (eds.). Between Liberalism and Oppression; the politics of Structural Adjustment in Africa. Dakar: Coderia.

[17] Bangura, Y. (1986), "Structural Adjustment" and the Political question" in Review of African Political Economy. London: ROAPE, No. 37.

[18] Bella, C. (1970), Ritual Theory, Ritual Practices, New York and Oxford: Oxford University Press.

[19] Bilton, T. (1977), Introduction to Sociology, London: Macmillian Press.

[20] Downes, R.M. (1971). Tiv Religion. Ibadan: University Press

[21] Egbuna, O.B. (1973). The ABC of Black Power Lagos: Third world First Publication.

[22] Fadahaui, A.A. (1992), "The implication of Structural Adjustment Programme for the planning of the Nigerian Economy". In Osagie, E. (ed). Structural Adjustment Programme in the Nigerian economy. NPSS, Kura.

[23] Fola, T. (2008). Violence in Nigeria: The Crises of Religious Politics and Secular Ideologies, Rochester, University of Roche ster Press.

[24] Gail, M.I. (1972), Values in Transition: A Handbook, New York. John Wiley.

[25] Gana, E. (2007) African Traditional Values and the Sustenance of Democracy in Nigeria, Journal of Christian Religion and Education, Zaria: The Nigerian Association for the Study of Christian Religion Education

[26] Gini, F.M. (1992), 'Fiscal aspects of SAP in Nigeria; Theoretical issues' in Eghosa Osagie (ed) SAP in The Nigerian Economy: NIPSS publication Kuru-Jos.

[27] Gray, B. (1992), "Measuring food security in United States: guide to Measuring Household food security (Revered), Alexandria: Office of analysis, nutrition, and evaluation.

[28] Idowu, B. 91973), African Traditional Religions: A Definition, London: SCM Press Ltd

[29] Idyorough, A.E. (1980) Sociological Analysis of Social Change in Contemporary Africa. Jos: Deka Publications.

[30] Ikenga-Metuh, E (1987), Comparative Studies of African Religions. Onitsha: Imico Publishers

[31] Ikenga-Metuh (1985), African Religion in Western Conceptual Schemes: The Problem of Interpretation, Ibadan, Pastoral Institute Bodija

[32] Ihonvbere, J.O. (1991), "Structural Adjustment in Nigeria" in Debt and Democracy: Alternative Strategies for Africa. Ben Turok (ed.) IFAA.

[33] Imo, C.O. (1984), Religion and the Unity of the Nigerian Nation. Germany: Almqvist and Wiksell International.

[34] Iyoha, A.M. (2002), "Impact of the structural adjustment programme on the structure of Nigeria's foreign Trade" In Osagie, E. (ed.) Structural Adjustment Programme in the Nigerian Economy. Nipss, Kuru.

[35] Julius, (1991), "Structural Adjustment in Nigeria" in Debt and Democracy: Alternative Strategies for Africa. Ben Turok (ed.) IFAA.

[36] Kalu, O.U. (1986), "The God's in Retreat: Models for Interpreting Religious Change in Africa," in E.I. Metuh (ed.) The God in Retreat: Continuity and Change in African Religions, Enugu, Fourth Dimension Press.

[37] Kluckhon, C. (1961), "The Study of Values," in N. Barret (ed.) Values in America, Notre Dame Indiana, University of Notre Dame Press.

[38] Kukah, M.H. (2002). Religion, Politics and Power in Northern Nigeria. Ibadan: Spectrum Books.

[39] Mai-Lafia, D.I. (1997). "Managing a mono-cultural Economy: A Diagnostic and Perspective Analysis of the Effects of Nigeria's Dependence on Oil" in Jos Journal of Social Issues, Vol. 1, No. 1 Jos: University of Jos Publication.

[40] Maquet, J (1972). Africanity: The Cultural Unit of Black Africa, New York: Oxford University Press.

[41] Mbiti, J.S. (1969). African Religions and Philosophy, Ibadan: Heinemann

[42] Majasan, J.A. (1976), “Traditional System of Education in Nigeria, III” Nigeria Magazine.

[43] Morris, C. (1956), Varieties of Human Value, Chicago, University of Chicago après Mazrui, A. A. (1980). The African Condition London: Heinemann National Concord, (1987), Dec. 12

[44] Nkrumah, K. (1975). "I speak freedom", In: Mutiso, G.C. and Roio, S.W. (Eds.), Readings in African Political thought London: Heinemann

[45] Ngosian, K. (1975). "I speak freedom", In: Mutiso, G.C. and Roio, S.W. (Eds.), Readings in African Political thought London: Heinemann.

[46] Northcote, T. (1969), Anthropological Report on Edo Peoples of Nigeria, Part I, Land and Customs, New York: Negro University.

[47] Olayide, S.O. and Eassang S.M. (1976), Population and Employment in S.O. Olayide (ed) Economic Survey of Nigeria, Ibadan, Aromolaran Publishing Company Ltd.

[48] Onaiyekan, J. (1989), (ed.), Religion, Peace and Justice in Nigeria: Breaking New Grounds, Communique of the Catholic Bishops Conference of Nigeria, February 1989 and related documents, IIorin.

[49] O’Neil, Dennis, (2006), “Overview of Religion” an internet article available at http://anthro.palomar.edu/religion/rel_1.htm

[50] Osagie, E. (1992), (ed.) Structural Adjustment Programme in the Nigerian economy, in Kuru.

[51] Pratt, J.B. (1949). The Religious Consciousness. New York: Macmillan Press.

[52] Raths, L.E. Harmin, M. and S.B Simon, Values and Teaching Col-umbus, Ohio, Charles E. Merrill.

[53] Rogers, C. (1969), Freedom to Learn, Columbia, Ohio, C.E. Merrill.

[54] Tillich, Paul, (1959). Theology of Culture, New York: Oxford University Press.

[55] The Nigerian economist, Dec. (1988),-Jan 2, 1989

[56] Ukechukwu, C.M. (1992), "Religious Values, Social Justice and Peace in the Nigerian Context" in Religion and Peace in Multi-Faith Nigeria(edited by Jacob K. Olupona), Ile-Ife: Obafemi Awolowo University. 
[57] Ushe M.U. (2010), The Mortgage Culture of Tiv Death and Burial Rites, Lagos: Vast Publishers Ushe, M.N (2007), Kpôr of Tiv Culture, (Enugu: San Press Ltd

[58] Waardenburg, Jacques, (1999). Classical Approaches to the Study of Religion: Aims, Methods and Theories of Research. Walter de Gruyter, Berlin \& New York.

[59] Weber, Marx, (1992). The Protestant Ethnic and the Spirit of Capitalism, London: Rutledge (first Published in German1904-5).

[60] West Africa, March 31dt, 1975.

[61] William, G. (1976), Nigerian: Economy and Society, Rex Collings, London.

[62] Williams, G. (1980), State and Society in Nigeria Williams, and Afrografika

[63] Wikipedia Encyclopedia (2007). "Values". Retrieved May 20, 2008 from free wikipedia encyclopedia-on line

[64] Yusuf, B. (1986) 'Crisis and Adjustment' The Experience of Nigerian Workers in The IMF, The World Bank and the African Debt: The Social and Political Impact. Zed Books Ltd. IFAA.

[65] Zuwaghu, A.B. (1986), "The State, Economic Crisis and the Real Content of Capitalist Development in Nigeria" in Siddique M. and Tony E. (eds.) Nigeria: A Republic in Ruins. Gaskiya Corporation Ltd. Zaria 